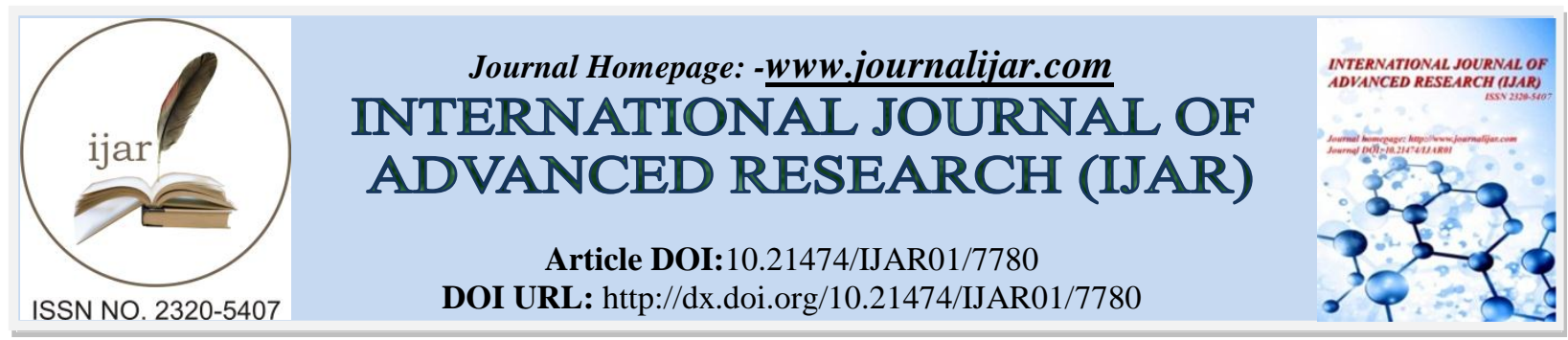

RESEARCH ARTICLE

\title{
THE IMPORTANCE OF EVALUATING THE EFFICIENCY OF THE ACTIVITIES OF THE STATE AUTHORITIES REPRESENTATIVE BODIES ON THE PLACES IN UZBEKISTAN.
}

\author{
Israilova Zarina Sadriddinovna.
}

Phd student, Academy of State Governance under the President of Republic of Uzbekistan.

\section{Manuscript Info}

\section{Manuscript History}

Received: 1 August 2018

Final Accepted: 3 September 2018

Published: October 2018

Keywords:-

representative bodies of state power on the ground, efficiency, evaluation criteria, mechanism, assessing.

\begin{abstract}
The article is devoted to the importance of assessing the effectiveness of the activities of representative bodies of state power on the ground in the Republic of Uzbekistan. The tasks of effectiveness evaluation are determined. The mechanism for assessing the activities of the Kengashes of People's Deputies is considered as a way of analyzing the effectiveness of the law.Particular attention is paid to the need for the development and normative consolidation of a unified system of criteria for assessing their effectiveness.
\end{abstract}

Copy Right, IJAR, 2018,. All rights reserved.

\section{Introduction:-}

In recent years, reforms have been carried out in many spheres of state and public life, including in the process of structural and structural development of public authorities. Since the introduction of the independence of the Republic of Uzbekistan, it has been systematically implementing administrative reforms aimed at creating an optimal and effective system of public administration, as only effective state authorities are capable of solving urgent social, economic, political, legal problems and creating conditions for improving the quality and life of the population.

In the words of the first President I. Karimov, "we have an objective and critical assessment of the place we occupy in today's world, the consistent approach to the ever-increasing demands of life", the further deepening of democratic reforms, "first of all, it is important to strengthen the legal norms, and, if necessary, adopt special laws "[1].

The state and development of the region, districts and cities depend largely on how effectively management is organized in it. Effective management assumes that the results of activities must meet the social expectations of people: the work of the state authority in the field should be aimed at ensuring the stability and development of the inhabitants of the territory, to meet the needs of the population. The modern concept of city management should be based on the interests and needs of citizens and be aimed at enhancing their citizenship. Therefore, in the management of state power in the field, it is of particular importance not only to receive objective information about the state of the city's society and its development trends, but also to develop an understanding of the attitude of the citizens themselves to the activities of the region, the city and the city, the local executive authorities, including the local authority representative power. It seems that there is a need to determine the value of the effectiveness evaluation system for representative bodies of state power on the ground in order to take one of the following decisions on it:

1. to state the necessity of elaborating an analysis of the activities of a representative state authority on the ground;

2. to recognize the positive importance of developing a system for assessing the effectiveness of the representative body of state power in the field and the need to further develop it as an important factor in improving the law 
"On state power in the field". Within the framework of the "Concept of Administrative Reform in the Republic of Uzbekistan" of September 8, 2017, No. UP-5185, it was stated that there is a superficial assessment of the mechanism of activity of local authorities, which in most cases do not reflect the real situation on the ground

This situation also poses new challenges for the study of the activities of representative bodies of state power in the field.

Before proceeding directly to the consideration of a further mechanism for assessing the effectiveness of the activities of the representative body of state power in the field in the Republic of Uzbekistan, it is necessary to determine the content of the key category of our research - the notion of Efficiency - a universal concept actively used in science and widely studied by various scientific disciplines. Throughout history, mankind has sought to achieve maximum results at the cost of minimal effort. Largely, this desire has become the key to progress, the emergence of scientific knowledge and cultural values. Essentially, it is the effectiveness of the system, whether social, economic or technological, that determines the fate of the system from the perspective of development, selfimprovement and survival.

Firstly, the definition of the term "efficiency" should be clarified. The concept of "efficiency" is derived from the Latin "effect" (effectus), ie. Result, consequence of any reasons, actions. Accordingly, efficiency means efficiency, effectiveness, but not any, but pre-planned, targeted, leading to the necessary results. It is easy to see that in the basis of the concept of "effectiveness" are two elements: costs (resources, funds, costs, etc.) and the result (goal, task, etc.). In this case, efficiency is defined as the ratio of these elements in the presence of a positive result. The categories "resources", "costs", "costs" are rarely found in the legal literature. In this regard, a fair question arises: is the assessment of the effectiveness of the activities of representative bodies of state power in the field in the legal plane, ie, is it of interest to representatives of the legal community, or is it the subject of research of specialists in public administration, personnel management, economists?[3]

We believe that the study of the effectiveness of the activities of representative bodies of state power in the field has a direct connection with the problem of the effectiveness of legal regulation. The analysis of the activities of the representative body of state power on the ground allows assessing not only the work of specific officials, but, most importantly, analyzing the quality of legislation regulating this or that sphere of social relations, identifying defects and gaps in legal regulation, and proposing ways to eliminate them. By assessing the activities of representative bodies of state power on the ground, points of discrepancy between the current legal regulation and real existing public relations should be revealed. We believe that from the point of view of effectiveness, first of all, the activities of those subjects of law that are legally charged with the task of solving the tasks of representative bodies of state power on the ground and creating conditions for its implementation and development on the territory of the Republic of Uzbekistan should be considered.

The effectiveness evaluation should be introduced in order to analyze the work of the regional authorities, which allows identifying those areas of their activities for which the functions of representative government bodies are not being effectively implemented, to determine the reasons for the existing difficulties, and to work out the best ways to solve them. We need to develop clear criteria that would allow us to judge who is working and how - regardless, at what level

At the core of the mechanism for assessing the effectiveness of the activities of representative bodies of state power on the ground is the idea of a fundamental community of state tasks and tasks facing the Kengash of people's deputies.

To assess the effectiveness, quantitative indicators (for example, the frequency of mentioning a deputy in the media) and relative indicators, qualitative indicators (for example, the intensity and effectiveness of working with voters) should be used.

Relative indicators are also intended to reveal the opinion of the population about the work of the Kengashes of People's Deputies. For example, the population's satisfaction with the activities of the Kengashes of People's Deputies, including their information openness. The values of these indicators are calculated as a percentage of the number of people interviewed. 
The effectiveness of representative bodies of state power in the field should be determined not only by the number of decisions taken, but, above all, by their quality and the ability to implement the decisions taken. It is necessary to take into account the fact that the executors of these decisions are not directly subordinate persons, but the people as a whole. Therefore, the achievement of results is determined by the creation of incentives for appropriate behavior, interest in society.

Effective and truly effective activity of deputies of representative bodies of state power in the localities, the successful resolution of economic, political and social tasks depend in many respects on the personnel of the Kengashes of People's Deputies. That is why it is necessary to introduce the systems of professional training of deputies of the representative body of state power in the localities. Ensuring the professionalism of the deputies of the representative body of state power in the regions is achieved by raising the legal and professional training of deputies with the help of special training, the use of skills and experience. The sooner the deputies reach the required level of qualification, the more effective and fruitful will be their activities, and in the end will benefit society as a whole.

To paraphrase the well-known principle, for example: "money follows deeds". Thus, one of the tasks of assessing effectiveness is being implemented, namely, the promotion of deputies and employees of the Kengashes of People's Deputies is not to imitate a stormy activity, but to achieve real measurable results.

We believe that it is necessary to approach the formation of the list of indicators for assessing effectiveness in the most balanced and responsible manner, to strive to build on those tasks that the legislator has put before the representative bodies of state power on the ground. The list of efficiency criteria can be considered optimal if it reflects national priorities, without going beyond the competence of the Kengashes of People's Deputies.

Criteria of effectiveness are signs, facets, sides, manifestations of the processes (relations) under study, through the analysis of which it is possible to determine their level and quality, as well as compliance with the needs and interests of society. The indicators characterize the measure, the quantitative characteristics of the corresponding features, facets, etc. If the definition of performance indicators is the acquisition of certain "data", then the evaluation of indicators using performance criteria is the receipt of the necessary "information". Performance criteria determine the ratio of indicators. Performance indicators help identify realistic goals and bottlenecks in achieving them, assess the feasibility of the decision and choose a rational solution from several alternatives [3].

When forming a system of indicators of the effectiveness of a representative public authority in the field, the following indicators for assessing public administration can be identified:

1. Effectiveness is the degree to which the system achieves a representative body of state power in the field assigned to it. To measure it, compare the planned management results with the actual ones. Measuring effectiveness is aimed at assessing both the individual worker and the higher levels of management;

2. quality is the degree to which the management system meets the requirements and expectations for it;

3. job satisfaction - the prestige of working in the field of a representative state authority on the ground, a sense of security and confidence. The methods for measuring this indicator are based on determining the degree to which employees' representations of the socio-psychological conditions correspond to the actual conditions;

4. Introduction of innovations - it reflects the real use of new achievements in the field of management organization to achieve the set goals.

In addition, in the methodology of performance monitoring, it is recommended to consider the values of indicators in dynamics, i.e. let every representative body of state power in the field "start" at a certain level, but we need to compare the growth rates, rather than the total volumes. Nevertheless, it seems that in this direction the efficiency assessment mechanism is subject to further improvement. Evaluation of the activities of the Kengashes of People's Deputies will help to solve important tasks. First, the lists of indicators for assessing efficiency will to a large extent serve as reference points for the activities of representative bodies of state power in the field and thereby ensure that national goals are taken into account in their work. The reports of the heads of the Kengashes of People's Deputies on the achievement of performance indicators should be widely available, should be placed on the official websites of representative state authorities on the Internet, which will increase the level of publicity of the activities of the Kengashes of People's Deputies. The positive side of the evaluation of effectiveness is also the fact that it motivates the heads of the Kengashes of People's Deputies to show the best results of the work. It seems that the desire to be no worse than others will play a role in this. 
However, the key, in our opinion, importance of assessing the effectiveness of public authorities in the field is not in the possibility of analyzing the work of specific officials. Of course, this task should also be addressed by the efficiency assessment mechanism, but it is, rather, concomitant. Evaluation of the effectiveness of public authorities is designed to serve a deeper strategic goal. Its results reflect the effectiveness of the law, manifested not in paper, but in specific cases.

Performance indicators should serve as indicators of the quality and accessibility of services rendered by the Kengashi of People's Deputies to the population, services in the broadest sense of the word, i.e. those directions of activity of public authorities, in which the social function of the state and the Kengashes of people's deputies is expressed.

Thus, the results of assessing the effectiveness of the activities of representative bodies of state power in the field should primarily not encourage or punish deputies of the people's Kengashes, but take measures, including in the field of legal regulation.

\section{Bibliographic:-}

1. Further deepening of reforms and building civil society is a key factor in our bright future.Statement by President Islam Karimov at the solemn ceremony marking the 21st anniversary of adoption of the Constitution of the Republic of Uzbekistan

2. Decree of the President of the Republic of Uzbekistan from 08.09.1017 "On the approval of the concept of administrative reform in the Republic of Uzbekistan"

3. Z. Gimaev Analysis of approaches to the concept of "efficiency" in sociology, economics and engineering. Research Article. Bulletin of Bashkir University. 2010. T. 15. No. 1, 145 p.

4. Internet dictionary "Academician". URL: http: // dic.academic.ru.

5. Shatalova AN. The problem of developing indicators of the effectiveness of municipal management. / Actual issues of the development of modern society. 2017. From 197-200p. 